\title{
Pengaruh Latihan Fisik Terhadap Faktor Risiko Kardiometabolik (Kadar Glukosa Darah) Pada Wanita Usia Reproduktif
}

\author{
${ }^{1}$ Wahyuni, ${ }^{2}$ Martha Debora Korompis \\ ${ }^{1,2}$ Jurusan Kebidanan Poltekkes Kemenkes Manado; \\ Email: wahyuni0891@gmail.com
}

\begin{abstract}
ABSTRAK
Kardiometabolik merupakan sekumpulan kelainan metabolisme yang ditandai dengan lima kriteria yaitu obesitas abdominal, peningkatan kadar trigliserida, penurunan HDL-kolesterol, peningkatan kadar glukosa darah puasa, dan peningkatan tekanan darah.

Penelitian ini bertujuan mengetahui pengaruh latihan fisik terhadap faktor risiko kardiometabolik (kadar glukosa darah) pada wanita usia reproduktif di coastal area.

Penelitian ini menggunakan metode quasi eksperimen dengan rancangan one group pretest dan posttest. Penelitian dilaksanakan selama tiga bulan. Pengambilan sampel dilakukan secara purposif. Sampel sebanyak 117 orang wanita usia reproduktif yang terdiri atas 61 coastal area dan 56 noncoastal area. Dilakukan pengambilan darah untuk pemeriksaan kadar glukosa darah dengan menggunakan alat spektrofotometer sebelum dan setelah responden melakukan latihan fisik. Perbandingan kadar glukosa darah antara sampel yang berdomisili di coastal area dan non coastal area hanya dilakukan sebelum latihan fisik. Latihan fisik berupa senam aerobik 3 kali dalam seminggu selama 8 minggu dengan durasi 60 menit.

Hasil penelitian menunjukkan bahwa terdapat hubungan kategori kadar glukosa sebelum dan setelah latihan fisik (kategori normal dari 101 orang menjadi 115 orang, kategori rendah dari 10 orang manjadi tidak ada, dan kategori tinggi dari 6 orang menjadi 2 orang, dengan nilai $p=0.002$ ). Terdapat penurunan yang signifikan pada kadar glukosa darah setelah melakukan latihan fisik $(88.00 \mathrm{mg} / \mathrm{dL} \pm 13.22$ menjadi $82.00 \mathrm{mg} / \mathrm{dL} \pm 10.09$, nilai $p<0.001)$. Tidak terdapat perbedaan yang signifikan pada kadar glukosa berdasarkan domisili responden (nilai $p=0.195$ ).

Dengan demikian, latihan fisik dapat menurunkan kadar glukosa darah, sedangkan domisili coastal dan non coastal tidak berpengaruh terhadap kadar glukosa darah.
\end{abstract}

Kata Kunci : Latihan fisik, kadar glukosa darah

\begin{abstract}
Cardiometabolics is a set of metabolic abnormalities characterized by five criteria of abdominal obesity, elevated triglyceride levels, decreased HDL-cholesterol, elevated fasting blood glucose levels, and elevated blood pressure. The research aimed to investigate the effect of the physical exercise on the cardiometabolic risk factor (blood glucose level) of the reproductive age women in the coastal area. This research used the quasi experimental method with one-group pre-test and post-test design. The research was conducted for three months. Samples were taken using the purposive sampling technique. The samples comprised 117 reproductive age women (61 coastal area women and 56 noncoastal area women). The blood was taken to check the blood glucose level before and after the physical exercise using a spectrophotometer. The comparison of blood glucose level between the samples dwelling in the coastal area and non coastal area was only conducted before the physical exercise. The physical exercise was the aerobic gymnastics three times in a week for 8 weeks with the duration of 60 minutes. The research result indicates that there is the correlation between the glucose level before and after the physical exercise (normal category from 101 subjects to become 115 subjects, low category from 10 subjects to become none, and high category from 6 subjects to become 2 subjects, with the value of $p=0.002)$. There is the significant decrease of blood glucose level after the physical exercise $(88.00 \mathrm{mg}$ / $d L \pm 13.22$ to $82.00 \mathrm{mg} / d L \pm 10.09$, value of $p<0.001)$. There is no significant difference in the glucose level based on respondents' domicile (value of $p=0.195$ ). Consequently, the physical exercise
\end{abstract}

Volume 7 Nomor 2. Januari - Juni 2020 
can decrease the blood glucose level, while the coastal area and non-coastal area domiciles do not have the effect on the blood glucose level.

Keywords: Physical exercise, blood glucose level

\section{PENDAHULUAN}

Kardiometabolik atau sindrom
metabolik bukan merupakan suatu
penyakit, namun merupakan sekumpulan kelainan metabolisme yang ditandai dengan lima kriteria yaitu obesitas abdominal (80 $\mathrm{cm}$ pada perempuan dan $90 \mathrm{~cm}$ pada lakilaki), peningkatan kadar trigliserida, penurunan HDL-kolesterol, peningkatan kadar glukosa darah puasa (110-126 $\mathrm{mg} / \mathrm{ml}$ ), dan peningkatan tekanan darah. (1)

Prevalensi dari komponen sindrom metabolik yang terdiri dari diabetes mellitus $2,1 \%$, obesitas sentral $26,6 \%$, hipertensi $9,5 \%$, stroke $12,1 \%$ dan penyakit jantung $1,5 \%$. Prevalensi komponen sindrom metabolik di Provinsi Sumatera Barat dari tahun 2007 sampai tahun 2013 diantaranya prevalensi diebetes melitus dari 1,2\% menjadi $1,8 \%$, penyakit jantung dari $11,3 \%$ menjadi $1,2 \%$, hipertensi dari $8,4 \%$ menjadi $7,9 \%$, dan stroke $10,6 \%$ menjadi $12,2 \%$ obesitas sentral dari $18,2 \%$ menjadi $20 \%$. (2)

Sindrom metabolik terkait dengan obesitas yaitu keadaan dimana terdapat penimbunan kelebihan lemak di tubuh yang berlebihan pada seseorang. Menurut data Riskesdas tahun 2007, prevalensi obesitas pada penduduk berusia $\geq 15$ tahun berdasarkan Indeks Massa Tubuh (IMT) adalah $10,3 \%$ (laki-laki 13,9\%, perempuan 23,8\%). Sedangkan prevalensi overweight pada anak-anak usia 6-14 tahun adalah
9,5\% pada laki-laki dan $6,4 \%$ pada perempuan. Pada tahun 2013 menunjukkan bahwa, prevalensi gizi lebih secara nasional pada remaja umur 13-15 tahun di Indonesia sebesar $10,8 \%$, terdiri dari $8,3 \%$ gemuk dan $2,5 \%$ sangat gemuk atau obesitas. Prevalensi gizi lebih pada remaja umur 1618 tahun mengalami peningkatan yang signifikan dari tahun 2007 sebesar 1,4\% menjadi 7,3\% pada tahun 2013. (2)

Masalah obesitas ini perlu menjadi perhatian utama karena masalah ini mulai dialami oleh semua kalangan termasuk pada usia reproduktif. Adapun penyulit obesitas terkait dengan masalah reproduksi yaitu terjadinya penyulit pada kehamilan, meningkatnya risiko kematian baik untuk ibu maupun bayi serta meningkatnya risiko peningkatan tekanan darah ibu sebesar 10 kali lipat. Obesitas pada kehamilan juga akan mengakibatkan meningkatnya risiko birth defects, khususnya kelainan neural tube seperti spina bifida. Obesitas pada premenopause berhubungan dengan siklus menstruasi yang tidak teratur dan infertilitas. $^{\text {(3) }}$

Salah satu sindrom metabolik sebagai akibat dari obesitas yaitu diabetes mellitus (DM) dimana penyakit ini merupakan kategori penyakit tidak menular dan kejadiannya terus mengalami peningkatan setiap tahunnya. Diabetes mellitus juga memberi kontribusi yang lebih besar terhadap kematian. Menurut data WHO pada tahun 2012, dari 3,7 juta kematian di dunia, sebanyak 1,5 juta kematian 
disebabkan oleh DM dan DM merupakan penyebab kematian kelima pada wanita di dunia. Pada tahun 2015, sebanyak 415 juta orang dewasa (20-79 tahun) mengalami diabetes. Diperkirakan pada tahun 2040 jumlahnya menjadi 642 juta. (4)

Menurut data Riskesdas tahun 2013, terjadi peningkatan penderita diabetes mellitus dari 1,1\% pada tahun 2007 menjadi $2,1 \%$ pada tahun 2013. Dan sebanyak 0,6\% atau sekitar 1 juta orang pada kelompok umur 15 tahun merasakan gejala DM namun belum dapat dipastikan apakah menderita DM atau tidak. ${ }^{(2)}$

Penyakit diabetes, terutama diabetes tipe 2 sering disebut sebagai diabetes dewasa (adult-onset diabetes) karena biasanya muncul pada usia lanjut. Namun, seiring dengan bertambahnya berat badan anak pada usia muda, diabetes tipe 2 semakin banyak di jumpai pada remaja dan dewasa muda (usia reproduktif). Perkembangan diabetes tipe 2 ini sangat dipengaruhi oleh gaya hidup. ${ }^{(5)}$

Selain itu, ditemukan bahwa sindrom metabolik juga berpengaruh berdasarkan letak geografis dimana penduduk di daerah pesisir (coastal area) lebih berpeluang mengalami sindrom metabolik karena mereka lebih sering mengkonsumsi makanan laut (seafood). Makanan laut (seafood) merupakan salah satu makanan yang mempunyai kadar lemak yang tinggi. Konsumsi seafood dalam jumlah yang berlebihan dapat menyebabkan terjadinya peningkatan lemak di dalam darah yang dapat mempengaruhi jumlah insulin yang dibutuhkan untuk menguraikan glukosa, sehingga sulit untuk diubah menjadi energi. Hiperglikemia merupakan keadaan glukosa yang meningkat di dalam darah sebagai indikator untuk menentukan penyakit diabetes melitus (DM). ${ }^{(6)}$

Untuk mencegah dan menangani terjadinya peningkatan kejadian diabetes mellitus, American Diabetes Association (2002) mengeluarkan 4 pilar pengelolaan diabetes mellitus yaitu edukasi, terapi gizi medis, latihan jasmani/aktifitas fisik, dan intervensi farmakologis. Salah satu pengelolaan diabetes mellitus yang dapat dilakukan yaitu latihan fisik. Dengan melakukan latihan fisik secara sistematis dan intensif, dapat menurunkan kadar glukosa darah. Hal ini disebabkan karena ketika melakukan aktifitas fisik maka terjadi peningkatan kebutuhan glukosa pada otot sehingga terjadi penurunan kadar glukosa dalam darah. ${ }^{(7)}$

Mengingat tingginya kejadian diabetes mellitus di Indonesia terutama pada usia reproduktif, sehingga penting dilakukan usaha pencegahan sehingga jumlah penderita diabetes mellitus dapat berkurang. Penelitian ini bertujuan untuk mengetahui pengaruh latihan fisik terhadap faktor risiko kardiometabolik (kadar glukosa darah) pada wanita usia reproduktif.

METODE

\section{Lokasi dan Rancangan Penelitian}

Penelitian ini dilaksanakan pada tanggal 19 Februari - 07 Mei 2018. Lokasi di Prodi S2 Kebidanan Universitas Hasanuddin Makasar dan Akbid Tahirah Al Baeti Bulukumba Sulawesi Selatan. Penelitian ini menggunakan desain quasi eksperiment dengan rancangan one group pretest-posttest.

Populasi dan Sampel 
Populasi dalam penelitian ini adalah semua mahasiswa Prodi S2 Kebidanan Unhas dan Akbid Tahirah Al Baeti Bulukumba sejumlah 237 orang. Sampel dalam penelitian ini yaitu 117 orang dengan teknik pengambilan sampel yaitu purposive sampling yaitu responden yang memenuhi kriteria inklusi dan bersedia mengikuti penelitian ini dengan menandatangani informed consent yang telah dikeluarkan oleh Komite Etik Fakultas Kedokteran Universitas Hasanuddin.

\section{Metode Pengumpulan Data}

Pengukuran kadar glukosa darah menggunakan uji spektrofometri menggunakan metode glukosa oksidase / peroksidase (GOD-PAP). Data karakteristik responden (umur, dan domisili) diukur melalui data pada kuisioner. Data konsumsi makanan diukur dengan menggunakan formulir recall 24 jam pada minggu pertama, keempat, dan kedelapan. Selain itu dilakukan pengukuran lingkar lengan atas (LILA).

\section{Analisis Data}

Untuk menguji data berdistribusi normal/tidak menggunakan uji statistik normalitas. Taraf signifikan $(\alpha=0.05)$. Jika $p>0.05$, maka Ho diterima yaitu data berdistribusi normal. Untuk uji hipotesis menggunakan uji chi-square, wilcoxon dan mann whitney $u$

\section{HASIL}

Tabel 1 memperlihatkan karakteristik responden yang menjadi sampel dalam penelitian ini. Dari 117 responden, sebagian besar responden berumur $17-25$ tahun $(72.6 \%)$ yang merupakan kelompok umur risiko tinggi mengalami kardiometabolik.

Tabel 1. Distribusi karakteristik responden

\begin{tabular}{ccc}
\hline Umur & n & \% \\
\hline 17-25 tahun & 85 & 72.6 \\
26-35 tahun & 18 & 15.4 \\
36-45 tahun & 10 & 8.5 \\
46-55 tahun & 4 & 3.4 \\
Total & $\mathbf{1 1 7}$ & $\mathbf{1 0 0}$ \\
\hline
\end{tabular}

Tabel 2 menunjukkan bahwa dari 117 responden kategori kadar glukosa darah responden sebelum melakukan latihan fisik sebagian besar berada dalam kategori normal yaitu 101 responden (86.3\%), dan setelah latihan fisik jumlah responden dalam kategori normal bertambah manjadi 115 responden $(98.3 \%)$.

Tabel 2. Distribusi responden berdasarkan kategori kadar glukosa darah sebelum dan setelah latihan fisik

\begin{tabular}{lccccccccc}
\hline \multirow{1}{*}{ Variabel } & \multicolumn{4}{c}{ Kategori } & \multicolumn{2}{c}{ Total } \\
\cline { 2 - 7 } & \multicolumn{2}{c}{ Normal } & \multicolumn{2}{c}{ Rendah } & \multicolumn{2}{c}{ Tinggi } & & \\
& $\mathbf{n}$ & $\mathbf{\%}$ & $\mathbf{N}$ & $\mathbf{\%}$ & $\mathbf{n}$ & $\mathbf{\%}$ & $\mathbf{N}$ & $\boldsymbol{\%}$ \\
Kadar glukosa pre test & 101 & 86.3 & 10 & 7.7 & 6 & 5.1 & 117 & 100 \\
Kadar Glukosa post test & 115 & 98.3 & 0 & 0.0 & 2 & 1.7 & 117 & 100 \\
\hline
\end{tabular}


Tabel 3 menunjukkan bahwa terdapat sebelum dan setelah senam dengan nilai $p$ hubungan kategori kadar glukosa darah $(0.002)<0.05$

Tabel 3. Hubungan kategori kadar glukosa darah sebelum dan setelah latihan fisik

\begin{tabular}{|c|c|c|c|c|c|c|c|c|c|}
\hline \multirow[t]{3}{*}{ Variabel } & \multicolumn{6}{|c|}{ Kategori } & \multirow{2}{*}{\multicolumn{2}{|c|}{ Total }} & \multirow{3}{*}{ Nilai $p^{*}$} \\
\hline & \multicolumn{2}{|c|}{ Normal } & \multicolumn{2}{|c|}{ Rendah } & \multicolumn{2}{|c|}{ Tinggi } & & & \\
\hline & $\mathbf{N}$ & $\%$ & $\mathbf{n}$ & $\%$ & n & $\%$ & $\mathbf{N}$ & $\%$ & \\
\hline Pre test & 101 & 86.3 & 10 & 7.7 & 6 & 5.1 & 117 & 100 & 0.002 \\
\hline Post test & 115 & 100 & 0 & 0.0 & 2 & 1.7 & 117 & 100 & \\
\hline
\end{tabular}

*Uji Chi-Square

Tabel 4 menunjukkan bahwa rerata kadar glukosa pre test yaitu $87.62 \mathrm{mg} / \mathrm{dL} \pm$ 13.22 dan rerata kadar glukosa post test yaitu $84.04 \mathrm{mg} / \mathrm{dL} \pm 10.09$. Adapun median pada kadar glukosa pre yaitu $88.00 \mathrm{mg} / \mathrm{dL}$ dan kadar glukosa post yaitu 82.00. Dengan nilai $p<0.001$ yang berarti bahwa terdapat perbedaan yang signifikan pada kadar glukosa darah sebelum dan setelah melakukan latihan fisik.

Tabel 4. Perbedaan rata-rata kadar glukosa darah sebelum dan setelah latihan fisik

\begin{tabular}{cccc}
\hline Variabel & Mean $\mathbf{\pm}$ SD & Median & Nilai $\boldsymbol{p}^{*}$ \\
\hline Kadar glukosa pre & $87.62 \pm 13.22$ & 88.00 & \multirow{2}{*}{$p<0.001$} \\
Kadar glukosa post & $84.04 \pm 10.09$ & 82.00 & \\
\hline
\end{tabular}

*Uji Wilcoxon

Tabel 5 menunjukkan bahwa median pada kadar glukosa coastal yaitu $89.00 \mathrm{mg} / \mathrm{dL}$ dan median pada kadar glukosa noncoastal yaitu $85.15 \mathrm{mg} / \mathrm{dL}$ dengan nilai $p(0.195)>0.05$ yang berarti bahwa tidak terdapat perbedaan kadar glukosa darah berdasarkan domisili responden.

Tabel 5. Perbedaan kadar glukosa darah berdasarkan domisili responden

\begin{tabular}{ccc}
\hline Variabel & Median & Nilai $\boldsymbol{p}^{*}$ \\
\hline Kadar glukosa coastal & 89.00 & \multirow{2}{*}{0.195} \\
Kadar glukosa non coastal & 85.15 & \\
\hline Uji Mann Whitney $U$ & &
\end{tabular}

\section{PEMBAHASAN}

Penelitian ini menunjukkan bahwa latihan fisik mampu menjaga homeostasis kadar glukosa dalam darah. Dimana kadar glukosa pre test dengan kategori normal sebanyak 101 responden (86.3\%), kategori rendah 10 responden $(7.7 \%)$ dan kategori tinggi sebanyak 6 responden $(5.1 \%)$.
Sementara pada kadar glukosa post test terdapat 115 responden $(98.3 \%)$ dalam

kategori normal dan terdapat 2 responden (1.7\%) memiliki kadar glukosa dengan kategori tinggi, dan tidak ada responden yang memiliki kadar glukosa dengan kategori rendah. Adapun hasil uji chi square nilai $p(0.002)<0.005$, yang berarti 
bahwa terdapat hubungan kategori kadar glukosa darah pre dan post test. Hasil penelitian ini sejalan dengan penelitian sebelumnya, yang menyatakan bahwa terdapat hubungan antara aktivitas fisik dengan kadar glukosa darah puasa pada pasiean diabetes tipe 2 dengan nilai $p$ $(0.000)<0.05$. Hal ini menunjukkan bahwa dengan melakukan latihan fisik berupa senam aerobik, dapat membantu menjaga homeostasis kadar glukosa dalam darah dari kategori rendah menjadi normal dan dari kategori tinggi menjadi normal. ${ }^{(8)} \mathrm{Hal}$ ini disebabkan karena saat melakukan latihan fisik, otot berkontraksi sehingga mengubah ATP (Adenosina Trifosfat) menjadi ADP (Adenosin Difosfat) kemudian membentuk kembali ATP melalui reaksi adenilat siklase yang akan menghasilkan AMP (Adenosina Monofosfat) yang berfungsi mengaktifkan glikolisis dan adanya pelepasan epinefrin dapat membantu merangsang hati melakukan glikoneolisis dan glukoneogenesis melalui peningkatan konsentrasi cAMP (Adenosina Monofosfat Cyclic). (9) Sehingga dalam hal ini, hati berperan penting dalam mempertahankan kadar glukosa darah, jika terjadi kelebihan kadar glukosa darah, maka akan disimpan dalam hati dalam bentuk glikogen melalui proses glikogenesis dan jika kadar glukosa dalam darah menurun maka glikogen diubah menjadi glukosa dan dilepaskan ke dalam sirkulasi darah. ${ }^{(10)}$

Selain itu, dalam penelitian ini terdapat penurunan rerata kadar glukosa darah sebelum dan setelah melakukan latihan fisik dimana rerata kadar glukosa pre test yaitu $87.62 \mathrm{mg} / \mathrm{dL} \pm 13.22$ dan rerata kadar glukosa post test yaitu 84.04 $\mathrm{mg} / \mathrm{dL} \pm 10.09$. Adapun median pada kadar glukosa pre yaitu $88.00 \mathrm{mg} / \mathrm{dL}$ dan kadar glukosa post yaitu 82.00. Dengan nilai $p<$ 0.001 yang berarti bahwa terdapat perbedaan yang signifikan pada kadar glukosa darah sebelum dan setelah melakukan latihan fisik. Hasil penelitian ini, sejalan dengan penelitian sebelumnya, yang menyatakan bahwa terdapat perbedaan yang bermakna $(p<0.05)$ antara kadar glukosa puasa pada pada responden normal sebelum dan setelah senam selama 6 minggu. Hal ini disebabkan karena ketika melakukan latihan fisik, otot-otot aktif bergerak sehingga tidak dibutuhkan insulin untuk memasukkan glukosa ke dalam sel karena pada otot yang aktif, sensitivitas reseptor insulin menjadi meningkat sehingga ambilan glukosa ke otot menjadi meningkat dan secara otomatis menurunkan kadar glukosa dalam darah. ${ }^{(11)}$ Sama halnya dengan hasil penelitian, bahwa terdapat perbedaan kadar glukosa secara signifikan $(\mathrm{p}<0.05)$ sebalum dan setelah senam pada kelompok perlakuan pada pasien diabetes mellitus tipe 1 yang melakukan senam aerobik intensitas tinggi dibandingkan dengan kelompok perlakuan yang melakukan senam aerobik intensitas sedang. ${ }^{(12)}$ Dengan melakukan latihan fisik, dapat menurunkan lemak tubuh dan secara otomatis mampu meningkatkan sensitivitas insulin yang akan meningkatkan ambilan glukosa ke otot dan kadar glukosa darah menjadi berkurang. (13)

Adapun penelitian lain yang tidak sejalan dengan penelitian ini bahwa dengan melakukan uji wilcoxon yang menyatakan bahwa tidak ada pengaruh yang signifikan $(\mathrm{p}>0.05)$ antara latihan fisik aerobik terhadap kadar glukosa darah pada kelompok perlakuan dan kelompok kontrol pada wanita obesitas, meskipun pada rerata 
kadar masing-masing kelompok tampak mengalami penurunan kadar glukosa darah. Hal ini disebabkan karena pada penelitian ini dilakukan hanya dalam waktu 1 bulan. Waktu 1 bulan bisa saja dampak olahraga terhadap tubuh belum maksimal. ${ }^{(\mathbf{1 4})}$

Selain latihan fisik, domisili juga mempengaruhi kadar glukosa darah. namun, dalam penilitian ini menunjukkan bahwa tidak terdapat perbedaan kadar glukosa darah berdasarkan domisili responden dengan nilai $p(0.195)>0.05$. Hal ini disebabkan bahwa pada era seperti saat ini yakni adanya sarana dan infrastruktur yang memadai, sehingga masyarakat non coastal sudah mampu mengakses makanan yang dikonsumsi oleh masyarakat coastal begitupun sebaliknya. Selain itu berdasarkan data food recall responden, tidak terdapat perbedaan pola konsumsi makanan yang dapat mempengaruhi kadar glukosa pada responden baik di coastal area maupun non coastal. Sehingga tidak ada pengaruh antara domisili dengan faktor risiko kardiometabolik. Hasil penelitian ini sejalan dengan penelitian sebelumnya, yang menyatakan bahwa tidak ada hubungan antara konsumsi makanan laut dengan peningkatan kadar $\mathrm{HbA} 1 \mathrm{C}$ yang merupakan faktor prediktor munculnya diabetes mellitus dengan nilai $p(0.72)>0.05$. Berbeda dengan penelitian sebelumnya yang dilakukan, yang menyatakan bahwa terdapat hubungan asupan energi, serat, dan karbohidrat dengan kadar trigliserida dan kadar glukosa darah pada sampel vegetarian yang merupakan responden yang tinggal di daerah non coastal dengan nilai $p(0.001)<$ $0.05{ }^{15}$ Hal ini disebabkan karena pola makan penganut vegetarian cenderung lebih banyak mengonsumsi bahan makanan jenis kacang-kacangan, biji-bijian, sayuran, dan buah-buahan. Semua jenis bahan makanan tersebut mengandung serat larut air dan tidak larut air, dimana kedua jenis serat ini saling bersinergi, menekan KGD dan trigliserida postprandial serta menurunkan rasio insulin-glukosa postprandial melalui Peroxisome Proliferator Activated Receptor (PPAR). Pada akhirnya serat mengikat kelebihan metabolisme glukosa dan lemak yang selanjutnya dibuang bersama feses. ${ }^{(16)}$

Selain itu penelitian lain dilakukan pada gaya hidup suku Eskimo yang merupakan penduduk coastal menyatakan bahwa konsentrasi plasma $\omega$-3 FA (fatty acids) sangat berkorelasi dengan diet $\omega-3$ FA dan tingkat HDL dan berkorelasi terbalik dengan tingkat plasma insulin, insulin 2-jam (OGTT), HOMI-IR, 2-jam glukosa (OGTT), tingkat trigliserida dan tekanan darah diastolik. Dengan Konsumsi tinggi $\omega-3$ FA secara positif mempengaruhi komponen dari sindrom metabolik, sensitivitas insulin dan toleransi glukosa. Temuan ini menunjukkan bahwa konsumsi C20-C22 $\omega-3$ tinggi FA melindungi terhadap perkembangan sindrom metabolik dan intoleransi glukosa. (17)

Adapun penelitian sebelumnya yang dilakukan pada masyarakat yang melakukan diet Mediterania (daerah pegunungan) terbukti bahwa diet gaya Mediterania mampu mengurangi prevalensi sindro metabolik dan risiko kardiovaskular, hal ini disebabkan karena diet gaya mediterania lebih banyak mengkonsumsi makanan yang mengandung lemak tak jenuh tunggal, lemak tak jenuh ganda, asam lemak omega 3 dan serat. ${ }^{(18)}$ 


\section{KESIMPULAN}

Kami menyimpulkan bahwa terdapat hubungan kategori kadar glukosa darah sebelum dan setelah senam dengan nilai $p$ 0.002. Selain itu terdapat penurunan yang signifikan pada kadar glukosa darah sebelum dan setelah melakukan latihan fisik, dengan median kadar glukosa pre test yaitu $88.00 \mathrm{mg} / \mathrm{dL}$ dan median kadar glukosa post test yaitu $82.00 \mathrm{mg} / \mathrm{dL}$ dengan nilai $p<0.001$. Selain itu tidak ada perbedaan kadar glukosa darah pada daerah coastal dan non coastal dengan nilai $p$ 0.195 , sehingga tidak ada pengaruh antara domisili dengan faktor risiko kardiometabolik.

\section{SARAN}

Setelah dilakukannya penelitian ini diharapkan perlunya melakukan latihan fisik berupa senam aerobik guna menurunkan kadar glukosa darah. Dilakukan pemeriksaan hormon insulin pada sampel untuk lebih membuktikan bahwa latihan fisik juga mempengaruhi kadar insulin. Dilakukan kontrol pada jenis makanan yang dikonsumsi oleh responden.

\section{DAFTAR PUSTAKA}

1. Bustan. (2007). Epidemiologi Penyakit tidak Menular. Jakarta : Rineka Cipta

2. Riset Kesehatan Dasar (RISKESDAS). (2013). Sindrom Metabolik dan Diabetes Melitus. Diakses $01 \quad$ November $2017 . \quad$ Available from: http://www.depkes.go.id/resources/download/pusdatin/infodatin/infodatin-diabetes.pdf

3. Soegih A. (2009). Obesitas Permasalahan dan Terapi Praktis. Jakarta : Sagung Seto

4. Word Health Organization (WHO). (2016). Kejadian Diabetes Melitus di Dunia. Diakses 01 November 2017 Available from: http://www.searo.who.int/indonesia/topics/8-whd2016diabetes-facts-and-numbers-indonesian.pdf

5. Nathan D. (2010). Menaklukkan Diabetes. Jakarta : PT Bhuana Ilmu Populer

6. Misnadiarly. (2007). Obesitas Sebagai Faktor Risiko Beberapa Penyakit. Jakarta : Pustaka Obor Populer

7. Utomo O.M., Azam M., \& Anggraini D.N. (2012). Pengaruh senam terhadap kadar gula darah penderita diabetes. Diakses 25 Oktober 2017 Available from: http://journal.unnes.ac.id/sju/index.php/ujph.

8. Nurayati L., \& Adriani M. (2017). Hubungan Aktifitas Fisik dengan Kadar Gula Darah Puasa Penderita Diabetes Melitus Tipe 2 Association Between Physical Activity and Fasting Blood Glucose Among Type 2 Diabetes Mellitus patients, 80-87. https://doi.org/10.20473/amnt.v1.i2.2017.80-87

9. Paruntu M. (2015). Perbandingan kadar glukosa sebelum dan sesudah aktivitas fisik intensitas berat 1, 3(April), 1-5.

10. Guyton A.C., \& Hall J. (2006). Textbook of Medical Physiology. Philadelphia : WB Sounders Company

11. Berawi K.N., Fiana D.N., \& Putri A. (2012) . Pengaruh Senam Aerobik terhadap Kadar Glukosa Darah Puasa pada Peserta Senam Aerobik di Pusat Kebugaran Sonia Bandar Lampung. Lampung : Faculty of Medicine University Lampung, 36-43

12. Moser O., Tschakert G., Mueller A., \& Groeschl W. (2015). Effects of High-Intensity Interval Exercise versus Moderate Continuous Exercise on Glucose Homeostasis and 
Hormone Response in Patients with Type 1 Diabetes Mellitus Using Novel Ultra-LongActing Insulin, 1-18. https://doi.org/10.1371/journal.pone.0136489

13. Scott D., Harrison C. L., Hutchison S., Courten B.De, \& Stepto N. K. (2017). Exploring factors related to changes in body composition, insulin sensitivity and aerobic capacity in response to a 12-week exercise intervention in overweight and obese women with and without polycystic ovary syndrome, 1-13. https://doi.org/10.1371/journal.pone.0182412

14. Mengga D. (2013). Pengaruh Latihan Aerobik Terhadap Kadar Gula Darah Puasa Pada Dewasa Obes (Tesis). Makassar : Universitas Hasanuddin

15. Siahaan G., Nainggolan E., \& Lestrina D. (2015). Indonesian Journal of Human Nutrition, 2(1), 48-59.

16. Juhartini, Amra N., \& Muhammad R. (2017). Konsumsi ikan terhadap kadar hba1c pada diabetisi di Kota Ternate, 13(1), 32-37.

17. Ebbesson S. O. E., Risica P.M., Ebbeson L.O.E., Kennish J.M., \& Tejero M.E. (2008). Omega-3 fatty acids improve glucose tolerance and components of the metabolic syndrome in Alaskan Eskimos: the Alaska Siberia project Omega-3 Fatty Acids Improve Glucose Tolerance And Components Of The Metabolic Syndrome In Alaskan Eskimos:, 3982. Diakses 12 November 2017. Available from: https://doi.org/10.3402/ijch.v64i4.18016

18. Esposito K., Palo C.Di, Giugliano F., Giugliano G., Armiento M.D., \& Andrea F.D. (2008). Effect of a Mediterranean-Style Diet on Endothelial Dysfunction and in the Metabolic Syndrome, 292(12). 